\title{
Demographic Determinants of Students Susceptibility to Peer Victimization in Secondary Schools in Osun State, Nigeria
}

\author{
Ehindero Serifat Adefunke, \\ ${ }^{1}$ Department of Educational Foundations and Counselling, Faculty of Education, Obafemi Awolowo University, \\ Ile-Ife, Nigeria \\ *Correspondence: Department of Educational Foundations and Counselling, Faculty of Education, Obafemi \\ Awolowo University, Ile-Ife. Nigeria. E-mail: ehinderoga@gmail.com
}

Received: October 14, 2014

Accepted: November 24, $2014 \quad$ Online Published: January 19, 2015

doi:10.5430/wje.v5n1p58

URL: http://dx.doi.org/10.5430/wje.v5n1p58

\begin{abstract}
This study examined age, sex, class and religion as determinants of students' susceptibility to peer victimization. One thousand five hundred students from 10 public secondary schools were selected by stratified sampling technique using class level as strata. A validated multi-dimensional peer victimization scale (MPVS) was used to collect data for the study. Results showed that students in the age range 13-14years were more susceptible to peer victimization, there was a significant influence ofage on students' susceptibility to peer victimization $(\mathrm{Fc} 2,1428=7.45 ; \mathrm{p}<0.05)$. Itwas revealed that there was difference in the male and female susceptibility to peer victimization $(\mathrm{df}=1429 ; \mathrm{t}=4.72$; $\mathrm{p}<0.05)$. It was also found that class level has significant influence on students' susceptibility to peer victimization with more peer victimization at junior level $(\mathrm{Fc} 2,1428=6.95 ; \mathrm{p} 0.05)$. Based on religion, it was found that there is a significant influence of religion on students' susceptibility to peer victimization ( $\mathrm{Fc} 2,1412=33.47 ; \mathrm{p}<0.05)$ it showed that there was a significant difference in students' susceptibility to peer victimization based on religion. Implications for counselling support services and counsellor in schools for both at-risk (vulnerable) students and the school authority are discussed.
\end{abstract}

Keywords: peer victimization; secondary school students; susceptibility and behaviour

\section{Introduction}

Peer victimization has been around for as long as there was mankind because it was regarded / assumed to be as a normal part of childhood experience within the Nigerian multi-ethnic culture/context. However, it has become increasingly clear that peer victimization is no more a normal part of childhood, it is infact a problem needing the attention of more researchers. It is characterized as an aggressive behaviour that is intended to cause distress or commonly harm and it involves an imbalance of power or strength between the perpetrator and the victim and commonly occur overtime (Nansel, Overpeck, Pilla, Ruan, Simmons-Morton and Scheidt, 2001). Parents and indeed the public seem to condone or at least tolerate it. However, in recent times the problem has attracted the attention of researchers as well as school counsellors who have lured the phenomenon to core aspects of school learning and academic performance.Peer victimization has been defined by many researchers. The most widely used definition of peer victimization as opined by Olweus (1993) is when a person is repeatedly exposed to negative actions on the part of one or more other students. Negative actions are considered to be when someone purposefully inflicts or tries to inflict injury on another person. These actions may be physical, verbal, spreading rumours or excluding the victim from the group are common forms of peer victimization. Nickel, Krwaczyz, Forthber, Kettler, Leiberich and Muelbercher (2005) defined peer victimization as the intentional unprovoked abuse of power by one or more children to inflict pain or cause distress to another child on repeated occasions. Hawker \&Boulton (2000) also defined peer victimization as the experience among children of being a target of aggressive behaviour of other children who are not siblings and necessarily age mates. Smith (1991) described the act as an unprovoked attack that causes hurt of a psychological, social or physical nature.Morrison (2002) for example surmisedthat peer victimization in schools is a worldwide problem that can have negative consequences for the general school climate and the rights of students to learn in a safe and secure environment without fear. Peer victimization is now generating 
heightened anxiety among counsellors, school authority and parents as it now threatens learning, the sole purpose of schooling.It should be noted that the issue of peer victimization is a social issue requiring immediate attention of school authorities in Nigeria. It is reasonable to assume that the exposure of young people to victimization while in school will normally generate high level of social aggression which according to Farrington (1993) may persist into adulthood in the form of criminality, marital violence, child abuse and sexual harassment (Adeoye, Okonkwo and Makinde, 2014).

The school environment is supposed to be a place where students can feel safe and secure to learn and where they can count on being treated with care, dignity and respect. Peer victimization often occurs when there is little or no supervision such as on school playground and also on the way home (Olweus, 1993; Pepler et al., 1994). However, it is possible that the school authority probably might not be aware of peer victimization in schools in which it would be difficult for the victims to be assisted by the school authority. In most cases victims might not even report cases of peer victimization to the school counsellor (if there is any) or to the school administrator. Olweus (1994) stated that victims are known to be fearful of reporting such cases, this situation compounds the victim's emotional and psychosocial trauma. Peer victimization is hardly recognized as a problem because it is believed that Nigerian children must learn to tolerate it as part of the process of growing up(Obidi, 1990). But, because of its possible negative influence on the learning process, it is now being recognized that it can indeed impede the normal psychosocial and academic development of students. According to Smith (2000), peer victimization is an unprovoked attack that hurtsthe psychological, social or physical nature of the victim. Slee and Rigby (1993) opined that one out often children is persistentlyvictimized by their peers while many more children are victimized less severely.

Studies have reported that children experience peer victimization, for example in Australia, $20 \%$ of students are victimized every week, Crick and Grotpeter(1995)reported that boys are more likely to experience direct victimization whereas girls more than boys are likely to experience indirect victimization. Craig (1997) surmised that boys more than girls reported more physical forms of victimization and that girls tend to be victimized in more indirect ways such as gossiping and exclusion. Ehindero (2010) reported that male students were physically more susceptible to peer victimization than female students but that female students are socially and verbally more susceptible than male students. Slee (1994) reported that the number of boys and girls being victimized by bullies is about the same while others found that more boys are bullied (Rigby \& Slee, 1991). O'Moore and Hillery (1989) observed that $12.5 \%$ of boys and $5.6 \%$ of girls were frequently bullied. Hazler et al, (1991) stated that boys were reported as victims $73 \%$ of the time and girls $27 \%$ of the time. Crick and Grotpeter (1995), Bjorkqvist et al (1982) reported that boys are more likely to experience direct victimization whereas girls more than boys are likely to experience indirect victimization. Mynard and Joseph (2000) reported that boys experienced higher physical victimization and attack on property than girls. Girls on the other hand experienced more victimization on social manipulation while no significant difference was found between boys and girls on verbal victimization. Victimization among girls mostly involves less physical violence and can be covert form of victimization which may not likely be known to the public.

Boulton\& Underwood (1992) reported that bullies tend most often to victimize students who are the same age as they are followed by younger students. Zindi (1994) noted that most bullies were in the same grade level as well as the class as the victims followed by the same grade and a different class. Most researchers indicated that younger children are victimized than older ones. Generally, bullying was more common among younger children from the older students and declined with age(Hoover, Oliver and Hazler,1992). As a pervasive phenomenon, Whitney and Smith (1993) reported that peer victimization can begin as early as pre-school level but it generally starts in elementary school, peaks in middle school and declines throughout high school this corroborate with Olweus (1997) that the percentage of students who reported being victims of bullying decreases with age and also the higher the class level the lower the level of victimization. Asamu (2006) found that $22.5 \%$ of the students below 15 years of age are prone to peer victimization and that peer victimization was peculiar to junior students. This implies that students in junior class experiencing higher level of victimization than students in high class level.The age and class level have also been found to be significant predictors of being victimized.

It could be seen that peer victimization is a serious educational issue that requires immediate attention of school authorities at local, state and national levels as the phenomenon affects the academic ability of the students.If unchecked, peer victimization is gradually acquiring the sophistication of a cult-like criminal phenomenon thus providing a fertile ground for breeding cultists among students in secondary schools. In spite of all research findings on peer victimization, it has been observed that much have not been done on issues related to religion and peer victimization. Thus, the interest of this study is to examine how age, sex, class and religion (demographic factors) 
influence student's susceptibility to peer victimization in selected secondary schools in Nigeria.

\section{Methodology}

A survey research design was adopted for this study. One thousand five hundred students from 10 public secondary schools were selected by stratified random sampling technique using class levels as strata.The adapted version of the Multi-Dimensional Peer Victimization Scale (MPVS) was used to collect data for this study. This questionnaire contained two sections. Section A consisted of demographic characteristics of students. Section B contained items on Multi dimensional peer victimization scale by Mynard and Joseph (2000). Four items were added to the 16 items contained in the original Multidimensional Peer Victimization Scale (MPVS) to meet the specific purpose of the present study. The scale was then revalidated and found to possess satisfactory internal reliability with Cronbach's Alpha values of $0.85,0.78,0.77$ and 0.73 for physical victimization, verbal victimization, social manipulation and attack on property respectively. The scale has an overall reliability coefficient of 0.94 which is significant at 0.05 level. Permission was given to the researcher by the school authority to administer the questionnaire on the students in the classroom during school hours with the assistance of school teachers. The questionnaire was collected after completion, after collection it was discovered that some students did not complete filling of the questionnaire. Data were collated and analyzed using chi square, one way ANOVA and t-test.

\section{Result}

Hypothesis 0ne: There is no significant influence of age in students' susceptibility to Peer Victimization

The hypothesis tested states that the difference in students' susceptibility to peer victimization based on age is not significant. In testing the hypothesis, students sample werecategorized into three age groups; 9-12 years, 13-14 years and above 14 years. Students in the age bracket of 9-12 years were made up of 386 students, those in the 13-14 years were 426 include those in the 14 years old and above category were 619 students.

Table 1. Descriptive Statistics of Students' Susceptibility to Peer Victimization Based on Age

\begin{tabular}{llll}
\hline Students' Age & $\mathrm{N}$ & $\mathrm{X}$ & $\mathrm{SD}$ \\
\hline 9-12 years & 386 & 18.53 & 9.77 \\
13-14 years & 426 & 19.02 & 9.17 \\
Above 14 years & 619 & 16.89 & 9.35 \\
\hline
\end{tabular}

It could be observed from Table 1, that students in the age range 13-14 years were more susceptible to peer victimization having an average and standard score of $(x=19.02 \& \mathrm{SD}=9.17)$. This is followed by students in the age range 9-12 years with an average and standard deviation score $(\mathrm{x}=18.53 \& \mathrm{SD}=9.77)$. The students who were 14 years old and above were the least susceptible to peer victimization $(\mathrm{x}=16.89 \& \mathrm{SD}=9.35)$. As presented on the table, age is an important variable in students' susceptibility to peer victimization. Consequently, differences in students' age become important too. The strength of such differences was determined by subjecting the various students' age groups' susceptibility to peer victimization scores to Analysis of Variance. The result of the analysis is presented on table 2.

Table 2. Summary of ANOVA Showing the Influence of Age on Students' Susceptibility toPeer Victimization

\begin{tabular}{llllll}
\hline Source & Sum of Squares & Df & Mean Square & F & Sig \\
\hline Between Groups & 132.59 & 2 & & 7.45 & .001 \\
Within Groups & 126593.73 & 1428 & 88.65 & & \\
Total & 127915.32 & 1430 & & & \\
\hline
\end{tabular}

Table 2 shows that there is a significant difference between the ages at which students were susceptible to peer victimization (F2 $1428=7.45 ; \mathrm{P}<0.05)$. It thus implies that students experience peer victimization between ages 12-14 years than when they are older. Hence, hypothesis one which states that the differences in students' susceptibility to peer victimization based on age is not significant and it is rejected. That is, the hypothesis that states the difference in students 'susceptibility to peer victimization based on age is significant.

Hypothesis Two: There is no significant difference in Male and Female Students' Susceptibility to Peer Victimization 
Table 3. Summary of T-Test Showing Difference in Male and Female Students' Susceptibility to PeerVictimization

\begin{tabular}{lllllll}
\hline Sex & $\mathrm{N}$ & $\mathrm{X}$ & $\mathrm{SD}$ & $\mathrm{df}$ & $\mathrm{t}$ & $\mathrm{P}$ \\
\hline Male & 571 & 19.40 & 9.65 & 1429 & 4.72 & $<0.05$ \\
Female & 860 & 17.01 & 9.21 & & & \\
\hline
\end{tabular}

From table 3, the male students mean score on the scale is $19.40(\mathrm{SD}=9.65)$, the mean score of female is $17.01(\mathrm{SD}=$ 9.21) showing that there are differences in the male and female susceptibility to peer victimization. A t-test analysis of the difference in mean scores yielded a $\mathrm{t}$-value $(\mathrm{df}=1429 ; \mathrm{t}=4.72 ; \mathrm{P}<0.05)$ which is significant at 0.05 level of significance. It thus implies that there is a significant difference between male and female students 'susceptibility to peer victimization.

Hypothesis Three: There is No Significant Effect of Students' Class Level on Susceptibility to Peer Victimization

Table 4. Descriptive Statistics of Students' Susceptibility to Peer Victimization Based on Class Level

\begin{tabular}{llll}
\hline Class & $\mathrm{N}$ & $\mathrm{X}$ & $\mathrm{SD}$ \\
\hline JSS I & 596 & 16.38 & 8.96 \\
JSS II & 475 & 18.97 & 9.93 \\
JSS III & 360 & 17.80 & 9.50 \\
TOTAL & 1431 & 17.97 & 9.46 \\
\hline
\end{tabular}

From table 4, the mean score and standard deviation of the JSSI and JSSII students were as $(\mathrm{X}=16.38, \mathrm{SD}=8.96)$ and $(X=18.97, S D=9.93)$ respectively, while the averagemean score of the JSS III students on the scale was $(X=$ 17.97). The result implies that there are differences in susceptibility to peer victimization at class level, with more peer victimization at junior classes. The strength of the differences was determined by subjecting the differences in mean scores to ANOVA. The result is as presented on Table 5.

Table 5. Summary of ANOVA Showing Effect of Students' Class Level on Susceptibility to Peer Victimization

\begin{tabular}{|c|c|c|c|c|c|}
\hline Source & Sum of Square & $\mathrm{df}$ & Mean Square & $\mathrm{F}$ & $P$ \\
\hline Between Group & 1232.658 & 2 & 616.329 & 6.947 & $<0.05$ \\
\hline Within Group & 126682.664 & 1428 & 88.713 & & \\
\hline Total & 127915.322 & 1430 & & & \\
\hline
\end{tabular}

Table 5 with the F-value $(\mathrm{Fc} 2,1428=6.95 ; \mathrm{P}<0.05)$ shows that there is a significant difference in students' susceptibility to peer victimization based on class level. Therefore, hypothesis 3 is rejected. This implies that peer victimization is common among students in junior classes.

Hypothesis four: There is no significant influence of religion on students' susceptibility to peer victimization

Table 6. Descriptive Statistics of Students' Susceptibility to Peer Victimization Based on Religion

\begin{tabular}{lccc}
\hline Religion & $\mathrm{N}$ & $\mathrm{X}$ & Standard Deviation \\
\hline Christianity & 801 & 19.5556 & 9.52364 \\
Islam & 586 & 16.2884 & 9.09008 \\
Traditional & 28 & 9.2857 & 6.17556 \\
Total & 1415 & 17.9993 & 9.50355 \\
\hline
\end{tabular}

From Table 6, the mean scores and standard deviation of Christian and Muslim students stand at $(X=19.56, \mathrm{SD}=$ $9.52)$ and $(X=16.29, \mathrm{SD}=9.09)$ respectively, while the mean score of the 28 traditionalists on the scale was $(X=$ 9.29). The result implies that there is the effect of religion on students' susceptibility to peer victimization with more victimization on Christian students than that of other religions. The strength of the differences was determined by subjecting the differences in mean to ANOVA. The result is as presentedin Table 7.

Table 7. Summary of ANOVA Showing Effect of Religion on Students' Susceptibility to Peer Victimization

\begin{tabular}{llllll}
\hline & Sum of Squares & df & Mean Square & F & P \\
\hline Between Groups & 5781.246 & 2 & 2890.623 & & $<0.05$ \\
Within Groups & 121927.753 & 1412 & 86.351 & 33.475 & \\
Total & 127708.999 & 1414 & & & \\
\hline
\end{tabular}

The result of the ANOVA is presented in Table 7. The F-value $(\mathrm{F} 2,1412=3.48 ; \mathrm{P}<0.05)$ shows that there is a significant difference in students' susceptibility to peer victimization based on religion, Therefore, hypothesis 4 is rejected. That is, there is aneffect of religion on students 'susceptibility to peer victimization. 


\section{Discussion}

The result of the study revealed that secondary schoolstudents between the ages of 9-12years, 13-14 years experienced higher level of peer victimization than older students of $15 y e a r s$ and above, this result is similar to that reported byOlweus (1997 which showed that the percentage of students who reported being victims of peer victimization decreased with age. This is consistent with the concept of peer victimization which according to Farrington (1993) suggests that the oppression of a less powerful person by a more powerful individual or a group of person. The differences in class level in this case reflect the idea of power in Farrington's concept. Since younger students tend to possess less physical power, it is normal to report higher frequency of victimization when compared with older (more powerful) students. The higher status and privilege enjoyed by students in the senior classes over those enjoyed in junior classes is an additional factor to physical power reinforcing and accounting for the way students in the higher class victimize those in junior class.

Results of this study also showed that male and female victims of peer victimization were subjected to social manipulation and verbal victimization. This is corroborated by Mynard and Joseph (2000) that boys experienced higher physical victimization and attack on property than girls and girls on the other hand experienced more victimization on social manipulation while no significant difference was found between boys and girls on verbal victimization. However, male students were physically more susceptible to peer victimization than female students, but female students were socially and verbally more susceptible than male students. This seems to be rooted in cultural stereotypes and general perceptions that females are the 'weaker' sex and the lower status accorded them in the Nigeria society. It is common among male children to kick, beat and injure each other without complaining, crying or reporting to any authority to prove to their parents their masculinity and ability to absorb and tolerate potential victimization. This is culturally expected and acceptable within the Nigerian society. Result also revealed that female students' properties were attacked more frequently than their male counterparts. Again, this is most likely to be explained within a prevailing socio-cultural perception bias and power relations that females are the weaker sex and hence can be more easily exploited and victimized if necessary using force. The acceptance and tolerance of these cultural stereotypes, bias and attitude against female within the Nigerian society aggravates all sorts of victimization against female students. The idea of equality of male and female which is emphasized both in the National Policy on Education (2004) and in the Millennium Development Goals (MDGs) is yet to find concrete translation in Nigerian classrooms. This constitutes a professional challenge to counsellors and teachers alike.

Results of the study also showed that there is a significant effect of students' class level on susceptibility to peer victimization. Hence, students at lower levels of the secondary school was found to experience more peer victimization than those at the higher class level. Several studies corroborated this finding, Olweus1997, Asamu 2006, Jeong and Lee, 2013, that peer victimization was peculiar to junior class students. There is also the tendency for the rate of peer victimization to drop when they get to higher classes. This showed that students in junior classes are more victimized than those in higher classes. In order words, students in all the classes are likely to be victimized but not on the same level and rate. This can result into absenteeism and other negative effects of victimization which cut across classes and these are functions of the severity of victimization. The result revealed that there is difference in students' susceptibility to peer victimization based on religion with more victimization on students who are Christians, that is, difference in students' susceptibility to peer victimization based on religion is significant. The geographical zone from which the sample of the study was drawn is predominantly Christian. The numerical strength of students might also account for the greater victimization of Christian students than of other religions. Again, given the conservative attitude of the Yoruba of the Southwest, victimization based on religion is strange. However, the result of this study with respect to religion, it may be that those victimized Christians were unidentified by their mode of dressing or other visible behaviour or activities not necessarily the Christian religion per se. Religion seems not to have been a factor strong enough to influence students to engage in peer victimization as the results of the study would seem to suggest. Studies have found that children and youth that frequently attend religious services and have a high level of spiritual support from others in their community have the lowest level of violence. In addition, it seems impossible that students as young as those in the age bracket in this study would have been so influenced by religion in peer victimization phenomenon especially in the Southwest geo-political zone where violence and predisposition to it is at a minimum. Hence, peer victimization influenced by and based on religion is therefore not likely to play a significant role in the students peer victimization in schools in the Southwest geo-political zone. Some implications for counselling and counselling support services are necessary. The result of this study suggests among other things, lack of inadequate fund for counselling support services in schools. These support services if adequate, would have provided framework containing victimization related phenomena. The result also implies that the school should relate more with the students' home to mitigate the potential effects and 
predisposition factors to peer victimization. This is in line with Obasola (2013) that home is the most fertile breeding place for violent behaviour for example, a child who sees a parent or other family members engage in fight often is more likely to see violence as a way to solve problems and subsequently be more likely to abuse others or engage in violent act.

It is therefore, necessary to recommend that, schools should investigate and understand more of the factors in the home and schools which promote peer victimization in schools. It is necessary to understand authoritarian child rearing processes and devise means to intervening. It has been shown that frequent whipping may arouse violent behaviour from the child (McManus, 1995). Idleness among students have been attributed to peer victimization in other words lack of productive students' activities both at home and school usually provide opportunity for students to engage in peer victimization, hence students should be usefully engaged, for example, by assigning them homework. School counsellors and classroom teachers should also encourage collaborative academic work among students so as to develop healthy interpersonal relationships that tend to discourage any form of peer victimization. Students should be counselled on the importance of being at peace with each other.

A result of the study has clear implication for urgent intervention programme in counselling but as it has been reported in (Ehindero, 2008) that there is acute shortage of counselling support services in most public schools in the Nigeria. These results imply that schools should establish equipped and functional counselling support services staffed with qualified personnel. An elaborate counselling support intervention programme should also be developed focusing on at-risk and vulnerable students on issues such as negative impacts of peer victimization to both students development and to the teaching and learning process. Both students and teachers should be encouraged through an awareness / enlightenment program to report cases of peer victimization to the school counselors. Both at-risk and vulnerable students should also be separately counselled. Finally, the students should be allowed to develop an understanding of their own and evolve alternative coping strategies in a safe and supportive environment.

\section{References}

Adeoye, A. O., Okonkwo, E. N., \& Makinde, B. O. (2014). The Interactive Effect of Gender on the Effectiveness of Contingency Management and Cognitive Self Instruction onBullying Behaviour of Secondary School Students in Nigeria. Journal of Psychology and Behavioural Science, 2(2), 125-136.

Asamu, F. F. (2006). Correlates of bullying among secondary school students in Ibadan, North East Local Government Area of Oyo State. Unpublished M.Ed Thesis of ObafemiAwolowo University, Ile-Ife, Nigeria.

Balogun, S. K., Olapegba, P. O., \& Opayemi, A. S. (2006). Influence of Gender, Age, Religion andEthnicity on Peer Victimization among Primary Four Pupils in Ibadan, Nigeria.

Bjorkqvist, K., Ekman, K., \& Lagerspetz, K. (1982). Bullies and victims: Their ego picture, idealego picture, and normative ego picture. Scandinavian Journal of Psychology, 23, 307-313. http://dx.doi.org/10.1111/j.1467-9450.1982.tb00445.x

Boulton, M. J., \& Underwood, K. (1992). Bully/Victim problems among middle school children. BritishJournal of Education Psychology, 62, 73-87. http://dx.doi.org/10.1111/j.2044-8279.1992.tb01000.x

Craig, W. (1997). The relationship among aggression types, depression, and anxiety in bullies, victims, and bully/victims. Personality and Individual Differences, in press.

Crick, N. R., \& Grotpeter, J. K. (1995). Relational Aggression, Gender and Social -PsychologicalAdjustment. Child Development, 66, 710-722. http://dx.doi.org/10.2307/1131945

Ehindero, S. A. (2008). Peer victimization and Coping strategies among secondary school students in Osun State. Unpublished Ph.D Thesis of ObafemiAwolowo University, Ile-Ife.

Ehindero, S. A. (2010). Types and Prevalence of Peer Victimization among secondarySchool students in Osun State. Journal of Infonomics society, $1(1)$.

Farrington, D. P. (1993). Understanding and preventing victimization.In Tonry, M. \& Morris, M. (Eds.). Crime and Justice: An Annual Review of Research (Vol.17). Chicago: Universityof Chicago Press.

Federal Republic of Nigeria. (2004). National Policy on Education (2004).

Hawker, D. S. J., \& Boulton, .M. J. (2000). Twenty years of research on Peer victimization andpsychological maladjustment: A meta -analytic review of cross-sectional studies. Journal of child psychology and Psychiatry, 41, 441-455. http://dx.doi.org/10.1111/1469-7610.00629 
Hazler, R. J., Hoover, J. H., \& Oliver, R. (1991). Student perceptions of victimization by bulliesin school. Journal of Humanistic Education and Development, 29, 143-150. http://dx.doi.org/10.1002/j.2164-4683.1991.tb00018.x

Hoover, J. H., Oliver, R. L., \& Hazler, R. J. (1992). Bullying: Perceptions of adolescent victimsin the Midwestern USA. School Psychology International, 13, 5-16. http://dx.doi.org/10.1177/0143034392131001

Jeong, S., \& Lee, B. H. (2013). Multilevel Examination of Peer Victimization and Bullying Preventions in Schools. Journal of Criminology, 2013.

McManus, M. (1995). Trouble Behaviour in Classroom ( $2^{\text {nd }}$ edition.). London: Routledge.

Morrison, B. (2002). Restorative Justice and School Violence: Building Theory and Practice. In Debarbieux, E.and Blaya, C. (Eds.), Violence in Schools and Public Policies. Youth Violence and Social Exclusion Series. Elsevier, Paris.

Mynard, H., \& Joseph, S. (2000). Development of the Multidimensional Peer VictimizationScale. Aggressive Behaviour, 26, 169-178. http://dx.doi.org/10.1002/(SICI)1098-2337(2000)26:2<169::AID-AB3>3.0.CO;2-A

Nansel, T. R., Overpeck, M., Pilla, R. S., Ruan, W. J., Simons- Morton, B., \& Schdild, P. (2001). Bullying Behaviour among U.S. youth: Prevalence and association with psychosocialadjustment. Journal of American Medical Association, 285(16), 2094-2100. http://dx.doi.org/10.1001/jama.285.16.2094

Nickel, M. K.., Kraeczyz, J., Nickel, C., Forthber, P., Kettler, C., Leiberich, P., Muelbacher, M., Tritt, K., Mitterlehner, F. O., Lahmann, C., Rother, W. K., \& Loew, T. H. (2005). Anger, interpersonal relationships and health related quality of life in bullying boys who aretreated with outpatient family therapy. A randomized, perspective, controlled trial with 1year follow-up. Pediarica, 116, 247-254.

O’Moore, A. M., \& Hillery, B. (1989). Bullying in Dublin schools. Irish Journal of Psychology, 10(3), $426-441$. http://dx.doi.org/10.1080/03033910.1989.10557759

Obasola, K. E. (2013). Religious Imperative as a Panacea to crime and violence among youths inNigeria. European Journal of Business and Social Sciences, 2(8), 112-122.

Obidi, S. S. (1990). Indigenous moral education of the Yoruba in Nigeria. Nigerian Journal of Educational Foundations, 1, 29-44.

Olweus, D. (1993). Bullying at school-What we know and what we can do. Oxford: Blackwell Publishers.

Olweus, D. (1994). Victimization at School Long Term Outcomes for the Victims and Effective School Based Intervention Program. (L. Rowell Huesmann). New York: Plenum Press.

Olweus, D. (1997). Bully / Victim problems in School: Knowledge based and an effectiveintervention programme. Irish Journal of Psychology, 18(2), 170-190. http://dx.doi.org/10.1080/03033910.1997.10558138

Omoteso, B. A. (2010). Bullying Behaviour, its associated factors and psychological effectsamong secondary school students in Nigeria. The Journal of International Social Research, 3(10), 498-509.

Pepler, D. J., Craig, W. M., Ziegler, S., \& Charach, A. (1994). An evaluation of anti-bullyingintervention in Toronto schools. Canadian Journal of Community Mental Health, 13(2), 95-110. http://dx.doi.org/10.7870/cjcmh-1994-0014

Rigby, K. (1998). Victimization in schools and what to do about it. Markham, Pembroke.

Rigby, K., \& Slee, P. T. (1991). Bullying among Australian school children and implications forpsychological well-being. Journal of Social Psychology, 133(5), 615-627. http://dx.doi.org/10.1080/00224545.1991.9924646

Slee, P. T. (1994a). Life at school used to be so good. Youth Studies Australia, Summer.

Slee, P.T., \& Rigby, K. (1993). Australian school children's self appraisal of interpersonalrelations: The victimization experience. Child Psychiatry and Human Development, 23, 273-282. http://dx.doi.org/10.1007/BF00707680

Smith, P. K. (1991). The silent nightmare: Bullying and Victimization in school peer groups. The Psychologist, 4, 243-248.

Smith, P. K. (2000). Victimization and Harassment in schools and the rights of children. Children and Society, 14, 294-303. http://dx.doi.org/10.1111/j.1099-0860.2000.tb00184.x

Whitney, I., \& Smith, P. K. (1993). A survey of the nature and extent of bullying in junior/middleand secondary schools. Educational Research, 35(1), 3-25. http://dx.doi.org/10.1080/0013188930350101

Zindi, F. (1994). Bullying at boarding school: a Zimbabwe study. Research in Education, 23-32. 